ISSN: 2302-8556

E-Jurnal Akuntansi Universitas Udayana

Vol.22.2. Februari (2018): 1363-1388

DOI: https://doi.org/10.24843/EJA.2018.v22.i02.p20

\title{
Persepsi Keadilan Dan Ketidakpastian Lingkungan Sebagai Pemoderasi Pengaruh Partisipasi Penganggaran Pada Senjangan Anggaran
}

\author{
Ayunia Gina T. Marjana1 \\ Dodik Ariyanto $^{2}$
}

${ }^{1}$ Fakultas Ekonomi dan Bisnis Universitas Udayana (Unud), Bali, Indonesia
email: ayugiena@gmail.com / telp: +6289 668359853
${ }^{2}$ Fakultas Ekonomi dan Bisnis Universitas Udayana (Unud), Bali, Indonesia

\begin{abstract}
ABSTRAK
Penelitian ini bertujuan untuk menguji dan memberikan bukti empiris peran persepsi keadilan yang diproksikan dengan keadilan prosedural dan keadilan distributif, serta ketidakpastian lingkungan dalam memengaruhi hubungan partisipasi penganggaran pada senjangan anggaran. Penelitian ini dilakukan pada 28 hotel berbintang di Kabupaten Badung. Jumlah responden yang digunakan sebanyak 77 orang kepala departemen yang dipilih menggunakan teknik purposive sampling dengan kriteria responden yaitu kepala departemen akuntansi, kepala departemen front office, dan kepala departemen food \& beverages yang ikut serta dalam penyusunan anggaran dan telah menduduki jabatannya minimal satu tahun. Metode pengumpulan data dilakukan dengan metode survei menggunakan kuesioner. Teknik analisis data yang digunakan adalah Moderated Regression Analysis (MRA). Hasil akhir penelitian menyatakan bahwa variabel keadilan prosedural dan keadilan distributif memperlemah pengaruh partisipasi penganggaran pada senjangan anggaran. Sedangkan variabel ketidakpastian lingkungan memperkuat pengaruh partisipasi penganggaran pada senjangan anggaran
\end{abstract}

Kata kunci: Partisipasi penganggaran, keadilan prosedural, keadilan distributif, ketidakpastian lingkungan, senjangan anggaran

\begin{abstract}
This study aims to test and provide empirical evidence of the role of fairness perception that's proxied with procedural fairness and distributive fairness, and environmental uncertainty in influencing the relationship of budgetary participation in budgetary slack. This research was conducted on 28 star hotels in Badung regency. The number of respondents used was 77 heads of departments selected using purposive sampling with respondent criteria head of accounting department, head of front office department, and head of food \& beverages department who participated in budget and have occupied his position at least one year. Methods of data collection were conducted by survey method using questionnaire. Data analysis technique used is Moderated Regression Analysis (MRA). The final results of the study suggest that procedural fairness and distributive fairness weaken the influence of budgetary participation on budgetary slack. While environmental uncertainty strengthens the influence of budget participation on budget slack
\end{abstract}

Keywords: Participative budgeting, procedural fairness, distributive fairness, environmental uncertainty, budgetary slack 


\section{PENDAHULUAN}

Anggaran dapat digunakan oleh manajer sebagai sarana perencanaan dan pengendalian perusahaan. (Sujana, 2010). Anggaran sebagai alat perencanaan berisi rencana kegiatan dan sejumlah target yang harus dicapai oleh para manajer departemen suatu perusahaan untuk melaksanakan kegiatan tertentu dimasa mendatang (Kartika, 2010). Selain itu, anggaran merupakan alat pengendalian yang memungkinkan manajemen untuk menemukan bidang-bidang yang menjadi kekuatan dan kelemahan perusahaan (Ikhsan \& Ishak, 2008:161).

Anggaran juga memiliki dampak langsung terhadap perilaku manusia. Aspek keperilakuan dari penganggaran mengacu pada perilaku pihak-pihak yang terlibat dalam proses penyusunan anggaran (Wijayanthi, 2016). Perilaku positif yang ditimbulkan dari anggaran adalah ketika anggaran digunakan sebagai dasar dari penilaian kinerja maka manajer merasa mendapatkan motivasi sehingga akan meningkatkan kinerjanya. Sedangkan, perilaku negatif manajer akan mengganggap anggaran sebagai alat tekanan manajer puncak kepada para bawahannya (Desmayani, 2016). Perilaku negatif inilah yang pada dasarnya bertentangan dengan tujuan organisasi atau sering disebut sebagai perilaku disfungsional (Hansen \& Mowen, 2009:447). Raghunandan et al., (2012) menyatakan kecenderungan manajer untuk menciptakan senjangan dalam anggaran adalah salah satu hal yang ditimbulkan dari adanya perilaku negatif. 
ISSN: 2302-8556

E-Jurnal Akuntansi Universitas Udayana Vol.22.2. Februari (2018): 1363-1388

Senjangan anggaran merupakan masalah organisasi dan perilaku, dimana manajer sengaja mengatur kewajiban tambahan untuk sumber daya dari anggaran tertentu atau tidak menggunakan kemampuan produktif secara maksimal (Faria dan Silva, 2013). Jika ditinjau dari teori keagenan, senjangan anggaran timbul karena adanya perbedaan kepentingan antara prinsipal dan agen. Permasalahan ini terjadi karena manajer cenderung melakukan moral hazard untuk memaksimalkan utilitasnya sehingga merugikan prinsipal (Widanaputra dan Mimba, 2014). Sedangkan prinsipal menginginkan target anggaran harus mencerminkan apa yang sesungguhnya memang dapat dicapai organisasi secara maksimal. Manajer biasanya cenderung menganggarkan revenue yang lebih rendah (understated) dan menganggarkan costs yang lebih tinggi (overstated) (Tagwireyi, 2012). Senjangan anggaran dapat terjadi karena manajer berusaha untuk mencari cara melindungi dirinya sendiri dari risiko tidak tercapainya target anggaran (Ajibolade dan Akinniyi, 2013). Raudhiah et al. (2014) menyatakan senjangan anggaran digunakan sebagai alat untuk memanipulasi anggaran agar target anggaran lebih mudah untuk dicapai. Senjangan anggaran akan tinggi jika kontrol anggarannya rigid atau kaku (Stede, 2000).

Hotel layaknya perusahaan lain juga menyusun anggaran untuk melakukan perencanaan keuntungan perusahaan yang mencakup sumber pendapatan dan biaya-biaya dalam suatu periode (Wijayanthi, 2016). Metode penyusunan anggaran pada hotel menggunakan metode buttom-up. Metode buttom-up merupakan salah satu metode partisipasi dalam penyusunan anggaran, dimana 
manajer level bawah dan manajer level menengah diberikan kesempatan untuk ikut berpartisipasi dalam proses penyusunan anggaran dan disahkan oleh manajer level atas.

Partisipasi dalam menyusun anggaran digambarkan dengan proses individu untuk mencapai target dalam proses penganggaran dan adanya penghargaan bila target dapat dicapai (Ariawan, 2015). Partisipasi penganggaran ini diperlukan karena bawahan dianggap lebih mengetahui kondisi langsung bagiannya. Apriyandi (2011) menyatakan tingginya keterlibatan individu dalam penyusunan anggaran, akan meningkatkan rasa tanggung jawab untuk melaksanakan keputusan yang dihasilkan. Namun keterlibatan individu dalam penyusunan anggaran terkadang menimbulkan masalah yaitu senjangan anggaran atau budgetary slack (Saputra, 2017). Hansen dan Mowen (2011) menyatakan masuknya slack dalam anggaran adalah salah satu kelemahan dari anggaran partisipatif.

Hasil dari penelitian sebelumnya oleh Young (1985), Mahadewi (2014), Ariawan (2015), Desmayani (2016) dan Arista (2016) menyebutkan bahwa partisipasi penganggaran berpengaruh positif terhadap senjangan anggaran. Hal ini berarti bahwa, semakin tinggi tingkat partisipasi bawahan dalam proses penyusunan anggaran maka semakin tinggi pula tingkat senjangan anggaran yang akan dilakukan. Namun, hasil penelitian tersebut bertolak belakang dengan penelitian yang dilakukan oleh Ramdeen et al. (2007), Sujana (2010), Karsam (2013), Resen (2014), Nitiari (2015), dan Anggariani (2016) yang menunjukkan hasil empiris bahwa partisipasi penganggaran berpengaruh negatif pada senjangan 
ISSN: 2302-8556

E-Jurnal Akuntansi Universitas Udayana Vol.22.2. Februari (2018): 1363-1388

anggaran. Untuk mengatasi ketidakkonsistenan hasil-hasil penelitian sebelumnya, maka diperlukan pendekatan kontijensi (contingency approach).

Pendekatan kontijensi memungkinkan adanya variabel-variabel lain yang dapat bertindak sebagai pemoderasi yang memengaruhi hubungan antara partisipasi penganggaran dan senjangan anggaran (Wijayanthi, 2016). Ketidakkonsistenan hasil antara penelitian-penelitian sebelumnya menjadi motivasi peneliti untuk melakukan penelitian kembali mengenai pengaruh partisipasi penganggaran pada senjangan anggaran dengan menggunakan persepsi keadilan, yaitu keadilan prosedural dan keadilan distributif. Selain itu, peneliti juga menggunakan variabel ketidakpastian lingkungan sebagai variabel pemoderasi.

Teori keadilan mengasumsikan bahwa, persepsi dan kepercayaan seseorang tentang persepsi keadilan berhubungan erat dengan pekerjaan yang dilakukannya. Hal tersebut akan membentuk kepercayaan diri yang kuat dan ini akan memengaruhi perilaku dan sikap seseorang terhadap pekerjaan (Maria, 2012). Jika organisasi mampu menerapkan prosedur dan keputusan secara adil maka anggota organisasi akan merasakan keadilan prosedural tersebut (Ariawan, 2015). Hal tersebut didukung oleh penelitian yang dilakukan oleh Ozer dan Yilmaz (2011) yang menyatakan keadilan prosedural dalam penganggaran mampu mengurangi asimetri informasi dalam proses penyusunan anggaran, sehingga akan mengurangi keinginan karyawan melakukan senjangan anggaran. Keadilan distributif lebih mengarah kepada proporsionalitas, artinya karyawan merasa anggaran yang diterima telah sesuai kebutuhan. Keadilan distributif mengarah pada keadilan dari 
tingkat atas sampai bawah, sehingga setiap anggota organisasi merasa menerima sumberdaya yang layak (Arista, 2016). Maiga dan Jacobs (2007) menyatakan, Persepsi Keadilan (keadilan prosedural dan keadilan distributif) berpengaruh pada kepercayaan bawahan terhadap atasan sehingga memunculkan komitmen tujuan anggaran yang kemudian mengurangi keinginan karyawan untuk melakukan senjangan anggaran.

Ketidakpastian lingkungan juga menjadi sebuah kendala dalam penyusunan anggaran (Nitiari, 2015). Hal penting yang perlu diketahui adalah anggaran di hotel sifatnya sangat fleksibel karena usaha perhotelan sangat rentan terhadap isu dan ketidakpastian lingkungan. Hal ini mengandung makna bahwa anggaran di hotel akan mengalami revisi yang relatif sering dibandingkan dengan anggaran yang disusun di industri lain. Seperti misalnya ketidakpastian lingkungan yang terkait dengan isu keamanan, kesehatan, dan perubahan kebijakan pemerintah akan sangat berpengaruh pada anggaran yang disusun diawal, dimana kondisi tersebut belum bisa diprediksi sebelumnya (Widanaputra, dkk., 2009:132). Kondisi ketidakpastian lingkungan yang tinggi akan menyulitkan seseorang untuk memprediksi masa depan dan semakin sulit pula menciptakan senjangan anggaran (Kartika, 2010). Sebaliknya, ketidakpastian lingkungan yang rendah mendorong terjadinya senjangan anggaran, karena ketidakpastian lingkungan yang rendah memudahkan individu untuk dapat memprediksi keadaan, sehingga langkah-langkah yang akan diambil dapat direncanakan dengan lebih akurat (Falikhatun, 2007). 
ISSN: 2302-8556

E-Jurnal Akuntansi Universitas Udayana Vol.22.2. Februari (2018): 1363-1388

Bali merupakan destinasi pariwisata terbaik dunia yang selalu ramai didatangi wisatawan baik domestik maupun mancanegara. Hal ini tentunya mendorong berkembangnya dunia wisata dan bisnis perhotelan. Perkembangan hotel-hotel yang semakin meningkat menyebabkan terjadinya persaingan yang sengit antar hotel. Walaupun jumlah kunjungan wisatawan ke Bali setiap tahunnya mengalami peningkatan namun hal ini berbanding terbalik dengan rata-rata tingkat hunian kamar (room occupancy) hotel di Bali yang mengalami penurunan sejak 4 tahun terakhir. Rata-rata tingkat hunian kamar hotel di Bali disajikan dalam Tabel 1 berikut.

Tabel 1. Rata-Rata Tingkat Hunian Kamar Hotel Di Bali Tahun 2013-2016

\begin{tabular}{cc}
\hline Tahun & Rata-rata THK \\
\hline 2013 & $63.21 \%$ \\
2014 & $60,31 \%$ \\
2015 & $58,14 \%$ \\
2016 & $54,47 \%$ \\
\hline
\end{tabular}
Sumber : Dinas Pariwisata Daerah Provinsi Bali, 2017.

Kunjungan wisatawan yang meningkat dengan tingkat hunian kamar hotel yang mengalami penurunan menunjukkan bahwa persaingan bisnis industri perhotelan untuk memberikan pelayanan terbaik juga semakin meningkat. Hal ini juga memberikan isyarat bahwa adanya penurunan kinerja manajerial yang mungkin disebabkan oleh kurang baiknya perencanaan dan pengendalian yang disusun oleh manajer. Penyebab terjadinya hal tersebut bisa saja karena proses dalam penyusunan anggaran yang tidak tepat, dimana terdapat kemungkinan manajer menetapkan target anggaran yang lebih rendah dari yang seharusnya dapat 
dicapai, sehingga terjadi penurunan kinerja pada hotel.

Berdasarkan paparan tersebut, adapun rumusan masalah dalam penelitian ini adalah: 1) Apakah keadilan prosedural memoderasi hubungan antara partisipasi penganggaran dan senjangan anggaran? 2) Apakah keadilan distributif memoderasi hubungan antara partisipasi penganggaran dan senjangan anggaran? 3) Apakah ketidakpastian lingkungan memoderasi hubungan antara partisipasi penganggaran dan senjangan anggaran?

Penelitian ini diharapkan mampu memberikan manfaat, baik secara teoritis maupun paraktis. Secara teoritis, penelitian ini diharapkan dapat menjadi bukti empiris yang menambah wawasan ilmu kepada akademisi khususnya dibidang akuntansi keuangan dan perilaku, mengenai pengaruh partisipasi penganggaran pada senjangan anggaran dengan Persepsi Keadilan, yaitu keadilan prosedural dan keadilan distributif serta ketidakpastian lingkungan sebagai variabel pemoderasi, selain itu untuk membuktikan peran Teori Agensi dan teori pendukung lainnya dalam hubungannya dengan senjangan anggaran. Secara praktis, penelitian ini diharapkan mampu memberikan informasi bagi pihak-pihak yang terkait dalam penyusunan anggaran, baik itu manajer tingkat atas, manajer tingkat menengah maupun manajer tingkat bawah dalam mengambil keputusan terkait penyusunan anggaran sebagai sarana perencanaan dan pengendalian sehingga nantinya dapat meningkatkan kinerja perusahaan agar mampu bersaing demi kelangsungan hidup perusahaan. Serta penelitian ini juga diharapkan mampu memberikan informasi yang relevan dan memperkuat penelitian sebelumnya mengenai senjangan anggaran. 
ISSN: 2302-8556

E-Jurnal Akuntansi Universitas Udayana Vol.22.2. Februari (2018): 1363-1388

Ramdeen et al. (2007) menyatakan teori keagenan digunakan untuk menjelaskan terjadinya senjangan anggaran di industri perhotelan. Teori ini secara umum mengasumsikan bahwa prinsipal adalah risk-neutral dan agen adalah riskaverse and effort (Maria, 2012). Prinsipal dalam hal ini adalah pemegang saham (stakeholder) dan agen adalah Chief Executive Officer (CEO), namun dalam kondisi yang lebih spesifik di industri perhotelan, pemilik perusahaan merupakan prinsipal dan manajer adalah agennya. Masalah keagenan (agency conflict) muncul karena adanya perbedaan kepentingan antara prinsipal dan agen dalam penyusunan anggaran. Teori keagenan menjelaskan bahwa senjangan anggaran dapat dikaitkan dengan empat kondisi, yaitu: (1) Adanya asimetri informasi antara atasan dan bawahan (principal-agent), (2) Adanya ketidakpastian diantara bisnis dan output, (3) Adanya konflik terkait tujuan prinsipal dan agen, dan (4) kepentingan pribadi bawahan (agent) (Maria, 2012). Jika atasan menggunakan anggaran sebagai tolok ukur pengukuran kinerja bawahannya maka tidak menutup kemungkinan untuk manajer dapat bertindak oportunistik sehingga kinerjanya terlihat baik untuk mendapatkan penghargaan (reward) berdasarkan pencapaian anggaran tersebut. Kondisi inilah yang akan menimbulkan senjangan anggaran

Keadilan dalam proses (prosedur) penyusunan anggaran memegang peranan yang sangat penting. Keadilan prosedural (prosedural fairness) adalah keadaan dimana orang bekerja dalam sebuah sistem yang mengasumsikan bahwa prosedur tersebut diputuskan untuk digunakan secara adil dan jujur (Harryanto, 2017). Menurut Ozer dan Yilmaz (2011) semakin tinggi persepsi manajer terhadap 
keadilan prosedural, semakin rendah kemungkinan untuk menciptakan senjangan anggaran. Berdasarkan teori dan penelitian sebelumnya, maka dapat dirumuskan hipotesis pertama yakni sebagai berikut :

$\mathrm{H}_{1}$ : Semakin tinggi partisipasi penganggaran maka semakin rendah senjangan anggaran bagi penyusun anggaran dengan persepsi keadilan prosedural tinggi.

Karyawan dapat menganggap bahwa keadilan distributif adalah rasio antara input dan outputnya, bahwa orang akan membandingkan rasio input mereka terhadap hasil yang mereka hasilkan dengan orang lain dan melakukan penilaian terhadap keadilan (Harryanto, 2017). Maria (2012) menyatakan persepsi bawahan terhadap keadilan distributif selama proses penganggaran partisipatif dapat mengurangi masalah keagenan karena keadilan distributif akan meningkatkan pertukaran informasi antara atasan dan bawahan sehingga akan mengurangi asimetri informasi yang pada akhirnya akan mengurangi potensi terjadinya senjangan anggaran. Berdasarkan teori dan penelitian sebelumnya, maka dapat dirumuskan hipotesis kedua yakni sebagai berikut

$\mathrm{H}_{2}$ : Semakin tinggi partisipasi penganggaran maka semakin rendah senjangan anggaran bagi penyusun anggaran dengan persepsi keadilan distributif tinggi.

Ketidakpastian tidak hanya terkait dengan lingkungan fisik tetapi juga pengetahuan dan persepsi individu tentang lingkungan (Yilmaz dan Özer, 2011). Dalam kondisi lingkungan yang cenderung stabil (rendah) maka senjangan anggaran yang muncul akan meningkat pula. Seorang bawahan yang mempunyai partisipasi tinggi dalam anggaran dan menghadapi ketidakpastian lingkungan yang 
ISSN: 2302-8556

E-Jurnal Akuntansi Universitas Udayana

Vol.22.2. Februari (2018): 1363-1388

rendah, akan mampu menciptakan senjangan dalam anggaran (Kartika, 2010; Asak, 2016) Berdasarkan teori dan penelitian sebelumnya, maka dapat dirumuskan hipotesis ketiga yakni sebagai berikut :

$\mathrm{H}_{3}$ : Semakin tinggi partisipasi penganggaran maka semakin tinggi senjangan anggaran bagi penyusun anggaran yang menghadapi kondisi ketidakpastian lingkungan rendah.

\section{METODE PENELITIAN}

Penelitian ini menggunakan pendekatan kuantitatif yang berbentuk asosiatif. Menurut Sugiyono (2013:13), pendekatan kuantitatif adalah metode penelitian yang digunakan untuk meneliti populasi atau sampel tertentu yang bertujuan untuk menguji hipotesis yang telah ditetapkan. Lokasi atau wilayah penelitian ini adalah hotel bintang tiga sampai hotel bintang lima di Kabupaten Badung. Obyek dalam penelitian ini adalah partisipasi penganggaran, Persepsi Keadilan yang meliputi keadilan prosedural dan keadilan distributif, dan ketidakpastian lingkungan pada senjangan anggaran. Keadilan prosedural, keadilan distributif, dan ketidakpastian lingkungan pada penelitian ini berfungsi dalam memoderasi pengaruh partisipasi penganggaran dan senjangan anggaran.

Variabel bebas dalam penelitian ini adalah partisipasi penganggaran $\left(\mathrm{X}_{1}\right)$. Partisipasi Penganggaran adalah suatu proses penyusunan anggaran yang melibatkan semua level manajer untuk ikut berpartisipasi dalam proses penyusunan anggaran. Instrumen yang digunakan berupa kuesioner dengan lima item pernyataan. Variabel moderasi dalam penelitian ini adalah keadilan prosedural $\left(\mathrm{X}_{2}\right)$, keadilan distributif 
$\left(\mathrm{X}_{3}\right)$, dan ketidakpastian lingkungan $\left(\mathrm{X}_{4}\right)$. Keadilan prosedural adalah persepsi karyawan mengenai kewajaran prosedur yang diterapkan dalam semua proses alokasi sumber daya (Ozer dan Yilmas, 2011). Instrumen yang digunakan berupa kuesioner dengan lima item pernyataan terkait keadilan prosedural. Keadilan distributif adalah kesamaan atau keadilan berkaitan dengan pendistribusian sumberdaya pada setiap karyawan, dimana karyawan menerima distribusi sumber daya untuk mendapatkan keseimbangan antara masukan (input) dan keluaran (output) (Maiga dan Jacobs, 2007). Instrumen yang digunakan berupa kuesioner dengan delapan item pernyataan terkait keadilan distributif. Ketidakpastian Lingkungan adalah rasa ketidakmampuan seseorang untuk memprediksi suatu keadaan secara akurat, sehingga tidak mampu membuat keputusan yang tepat. Instrumen yang digunakan berupa kuesioner dengan dua belas item pernyataan terkait ketidakpastian lingkungan. Variabel dependen/terikat dalam penelitian ini adalah senjangan anggaran (Y). Senjangan anggaran adalah perbedaan antara jumlah yang diajukan oleh bawahan dengan jumlah sesungguhnya yang dapat dicapai. Instrumen yang digunakan berupa kuesioner dengan lima item pernyataan.

Populasi dalam penelitian ini adalah seluruh hotel bintang tiga, empat, dan lima anggota Perhimpunan Hotel dan Restoran Indonesia (PHRI) Kabupaten Badung, Provinsi Bali. Berdasarkan data yang di peroleh dari Perhimpunan Hotel \& Restoran Indonesia (PHRI) Provinsi Bali, terdapat 132 hotel bintang tiga, empat, dan lima di Kabupaten Badung. Pemilihan sampel penelitian didasarkan pada metode purposive sampling. Adapun kriteria yang digunakan untuk memilih sampel pada penelitian ini 
ISSN: 2302-8556

E-Jurnal Akuntansi Universitas Udayana Vol.22.2. Februari (2018): 1363-1388

adalah sebagai berikut : 1) Hotel berbintang yang bersedia menerima kuesioner dan menjadi responden. 2) Manajer yang menduduki jabatan sebagai manajer menengah (department head) dan terlibat dalam proses penyusunan anggaran pada kFront Office department, manajer menengah (department head) pada Food and Beverage department, dan manajer menengah (department head) pada Accounting department. 3) Telah menduduki jabatannya minimal 1 tahun dan memiliki pengalaman dalam melaksanakan anggaran yang disusunnya.

Model analisis data dan uji hipotesis dalam penelitian ini adalah model analisis regresi moderasi MRA (Moderated Regression Analysis). Rumus uji MRA digambarkan dalam persamaan regresi sebagai berikut.

$$
\begin{aligned}
& \mathrm{SA}=\alpha+\beta_{1} \mathrm{PP}+\beta_{2} \mathrm{KP}+\beta_{3} \mathrm{KD}+\beta_{4} \mathrm{KL}+\beta_{5}[\mathrm{PP} * \mathrm{KP}]+\beta_{6}[\mathrm{PP} * \mathrm{KD}] \\
& +\beta_{7}[\mathrm{PP} * \mathrm{KL}]+\varepsilon
\end{aligned}
$$

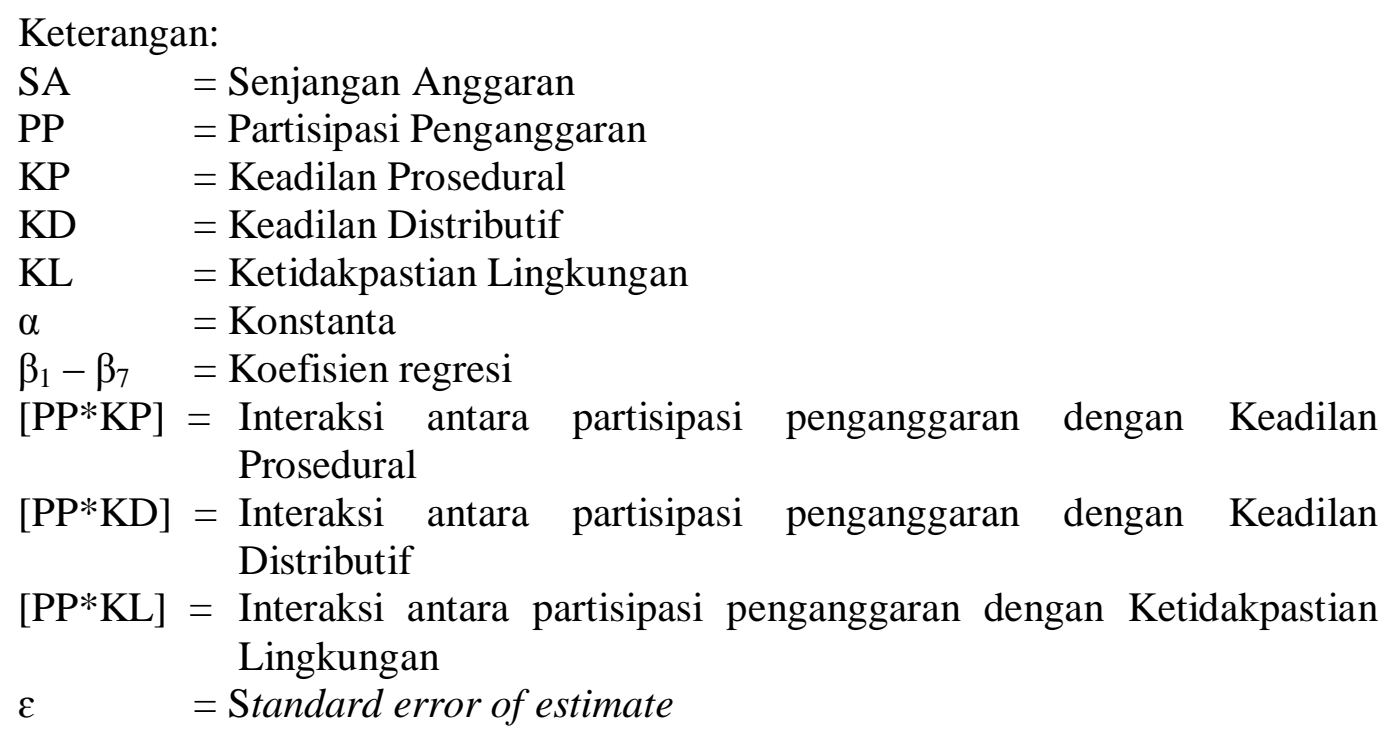




\section{HASIL DAN PEMBAHASAN}

Statistik deskriptif disajikan untuk memberikan informasi mengenai karakteristik variabel-variabel penelitian yang terdiri dari jumlah amatan, nilai minimum, nilai rata-rata, dan standar deviasi (simpangan baku) dengan $\mathrm{N}$ merupakan banyaknya responden penelitian. Hasil analisis statistik deskriptif dapat dilihat pada Tabel 2.

\section{Tabel 2.}

Hasil Statistik Deskriptif

\begin{tabular}{lccccc}
\hline \multicolumn{1}{c}{ Variabel } & N & Min. & Maks. & $\begin{array}{c}\text { Rata- } \\
\text { rata }\end{array}$ & $\begin{array}{c}\text { Simpangan } \\
\text { Baku }\end{array}$ \\
\hline Partisipasi Penganggaran $\left(\mathrm{X}_{1}\right)$ & 77 & 3,00 & 5,00 & 4,0571 & 0,49509 \\
Keadilan Prosedural $\left(\mathrm{X}_{2}\right)$ & 77 & 2,63 & 5,00 & 4,0260 & 0,44764 \\
Keadilan Distributif $\left(\mathrm{X}_{3}\right)$ & 77 & 2,80 & 5,00 & 3,8883 & 0,45595 \\
Ketidakpastian Lingkungan $\left(\mathrm{X}_{4}\right)$ & 77 & 2,75 & 4,83 & 3,9426 & 0,44390 \\
Senjangan Anggaran $(\mathrm{Y})$ & 77 & 3,00 & 5,00 & 4,0156 & 0,43136 \\
\hline
\end{tabular}

Sumber: Data diolah, 2017

Pada Tabel 2 variabel partisipasi penganggaran $\left(\mathrm{X}_{1}\right)$ memiliki nilai rata-rata sebesar 4,0571 dengan nilai minimum 3,00 dan nilai maksimum 5,00. Hal ini menunjukkan partisipasi dalam penyusunan anggaran pada hotel berbintang di Kabupaten Badung tinggi karena nilai rata-rata lebih mendekati nilai maksimal, yang artinya sebagian besar responden cenderung menjawab setuju pada 5 item pernyataan dalam variabel partisipasi penganggaran.

Variabel keadilan prosedural $\left(\mathrm{X}_{2}\right)$ memiliki nilai rata-rata sebesar 4,0260 dengan nilai minimum 2,63 dan nilai maksimum 5,00. Hal ini menunjukkan keadilan prosedural yang diterapkan dalam proses penyusunan anggaran pada hotel berbintang di Kabupaten Badung sudah terlaksana dengan baik. Nilai rata-rata lebih mendekati nilai maksimal menujukkan sebagian besar responden cenderung menjawab setuju 
ISSN: 2302-8556

E-Jurnal Akuntansi Universitas Udayana Vol.22.2. Februari (2018): 1363-1388

pada 8 item pernyataan dalam variabel keadilan prosedural.

Variabel keadilan distributif $\left(\mathrm{X}_{2}\right)$ memiliki nilai rata-rata sebesar 3,8883 dengan nilai minimum 2,80 dan nilai maksimum 5,00. Hal ini menunjukkan keadilan distributif yang diterapkan dalam proses penyusunan anggaran pada hotel berbintang di Kabupaten Badung sudah terlaksana dengan baik. Nilai rata-rata lebih mendekati nilai maksimal yang artinya sebagian besar responden cenderung menjawab setuju pada 5 item pernyataan dalam variabel keadilan distributif.

Variabel ketidakpastian lingkungan $\left(\mathrm{X}_{4}\right)$ memiliki nilai rata-rata sebesar 3,9426 dengan nilai minimum 2,75 dan nilai maksimum 4,83. Hal ini menunjukkan bahwa rata-rata responden menganggap ketidakpastian lingkungan yang diukur dengan menggunakan dimensi metode kerja, informasi dan pengambilan keputusan cenderung rendah (stabil). Nilai rata-rata lebih mendekati nilai maksimal yang artinya sebagian besar responden cenderung menjawab setuju pada 12 item pernyataan dalam variabel ketidakpastian lingkungan.

Variabel senjangan anggaran (Y) memiliki nilai rata-rata sebesar 4,0156 dengan nilai minimum 3,00 dan nilai maksimum 5,00. Hal ini menunjukkan terjadi senjangan anggaran dalam proses penyusunan anggaran pada hotel berbintang di Kabupaten Badung. Nilai rata-rata lebih mendekati nilai maksimal, yang artinya sebagian besar responden cenderung menjawab setuju pada 5 item pernyataan dalam variabel senjangan anggaran.

Metode analisis data dalam penelitian ini adalah metode analisis regresi moderasi. Analisis regresi moderasi digunakan untuk mengetahui dan menunjukkan 
status dan pengaruh dari variabel moderasi keadilan prosedural, keadilan distibutif, dan ketidakpastian lingkungan terhadap senjangan anggaran. Hasil analisis regresi moderasi yang disajikan pada Tabel 3 .

Tabel 3.

Hasil Moderated Regression Analysis (MRA)

\begin{tabular}{|c|c|c|c|c|c|c|}
\hline \multirow{2}{*}{\multicolumn{2}{|c|}{ Model }} & \multicolumn{2}{|c|}{ Unstandardized Coefficients } & \multirow{2}{*}{\begin{tabular}{|c|}
$\begin{array}{c}\text { Standardized } \\
\text { Coefficients }\end{array}$ \\
Beta
\end{tabular}} & \multirow[t]{2}{*}{$\mathbf{t}$} & \multirow[t]{2}{*}{ Sig. } \\
\hline & & $\mathbf{B}$ & Std. Error & & & \\
\hline \multirow[t]{8}{*}{1} & (Constant) & $1.892 \mathrm{E}-15$ & .070 & & .000 & 1.000 \\
\hline & PP & 2.486 & .877 & 2.486 & 2.836 & .006 \\
\hline & KP & -1.018 & .929 & -1.018 & -1.096 & .277 \\
\hline & KD & 2.044 & 1.446 & 2.044 & 1.414 & .162 \\
\hline & KL & -1.778 & .975 & -1.778 & -1.823 & .073 \\
\hline & $\mathrm{PP} * \mathrm{KP}$ & -1.500 & .613 & -1.500 & -2.446 & .017 \\
\hline & $\mathrm{PP} * \mathrm{KD}$ & -3.233 & 1.250 & -3.233 & -2.587 & .012 \\
\hline & $\mathrm{PP} * \mathrm{KL}$ & 3.435 & 1.487 & 3.435 & 2.310 & .024 \\
\hline \multicolumn{2}{|c|}{ F hitung } & $: \quad 18,958$ & & & & \\
\hline \multicolumn{2}{|c|}{ Signifikansi F } & $: \quad 0,000$ & & & & \\
\hline \multicolumn{2}{|c|}{ R Square } & $: 0,658$ & & & & \\
\hline \multicolumn{2}{|c|}{ Adjusted R Square } & $: \quad 0,623$ & & & & \\
\hline
\end{tabular}

Sumber: Data diolah, 2017

Koefisien Determinasi pada model regresi moderasi dilihat dari nilai Adjusted

$R$-Square sebesar 0,623. Hal ini berarti bahwa sebesar 0,623 atau $62,3 \%$ variasi senjangan anggaran mampu dijelaskan oleh variabel partisipasi penganggaran serta keadilan prosedural, keadilan distributif, dan ketidakpastian lingkungan sebagai pemoderasi. Sisanya sebesar 37,7\% dipengaruhi oleh variabel lain yang tidak masuk dalam model.

Uji F digunakan untuk melihat kelayakan model penelitian. Berdasarkan model yang telah dianalisis, diketahui $\mathrm{F}_{\text {hitung }}$ sebesar 18,958, signifikansi ( $p$-value) sebesar 0,000. Berdasarkan nilai toleransi yang diberikan yaitu $\alpha=5 \%$ dengan nilai signifikansi $0,000<\alpha(0,05)$, hal ini mengandung arti bahwa seluruh variabel mampu 
ISSN: 2302-8556

E-Jurnal Akuntansi Universitas Udayana Vol.22.2. Februari (2018): 1363-1388

memprediksi atau menjelaskan fenomena senjangan anggaran pada hotel berbintang di Kabupaten Badung dan model regresi yang digunakan dianggap layak uji.

Tabel 3 menunjukkan koefisien keadilan prosedural $\left(\beta_{2}\right)$ sebesar -1,018 dengan nilai signifikansi 0,277 lebih1besar dari $\alpha(0,277>0,05)$. Nilai koefisien interaksi $\left(\beta_{5}\right)$ antara keadilan prosedural dan partisipasi penganggaran sebesar -1,500 dengan nilai signifikansi sebesar 0,017 lebih kecil dari $\alpha(0,017<0,05)$. Nilai koefisien yang tidak signifikan pada variabel bebas dan nilai koefisien yang signifikan pada variabel interaksinya menandakan bahwa status dari keadilan prosedural adalah pure moderasi. Hal ini berarti hipotesis pertama $\left(\mathrm{H}_{1}\right)$ diterima, yaitu semakin tinggi partisipasi penganggaran maka semakin rendah senjangan anggaran bagi penyusun anggaran dengan persepsi keadilan prosedural tinggi.

Jawaban responden menunjukkan bahwa tingkat partisipasi penganggaran pada hotel berbintang di Kabupaten Badung cenderung tinggi, karena manajer menengah (department head) yang ikut serta dalam proses penyusunan anggaran sering menyatakan pendapat dan usulan tentang anggaran kepada pimpinan. Hal tersebut tentunya akan meningkatkan senjangan anggaran. Terjadinya senjangan anggaran yang diakibatkan oleh adanya proses partisipasi penganggaran pada hotel berbintang di Kabupaten Badung dapat berkurang apabila keadilan prosedural terlaksana dengan baik dan penerapannya konsisten dari waktu ke waktu sehingga persepsi manajer terhadap keadilan prosedural juga tinggi. Hal ini akan berdampak baik bagi manajer yang terlibat dalam proses penyusunan anggaran, karena ketika manajer merasa bahwa prosedur yang diterapkan dalam proses penganggaran sudah 
adil maka sebisa mungkin manajer akan menolak perilaku yang menyebabkan ketidakadilan dalam pelaksanaan prosedur sehingga senjangan anggaran dapat diminimalisir.

Tabel 3 menunjukkan koefisien keadilan distributif $\left(\beta_{3}\right)$ sebesar 12,044 dengan nilai signifikansi 0,162 lebih besar dari $\alpha(0,162>0,05)$. Nilai koefisien interaksi $\left(\beta_{6}\right)$ antara keadilan distributif dan partisipasi penganggaran sebesar -3,233 dengan nilai signifikansi sebesar 10,012 lebih kecil dari $\alpha(0,012<0,05)$. Nilai koefisien yang tidak signifikan pada variabel bebas dan nilai koefisien yang signifikan pada variabel interaksinya menandakan bahwa status dari keadilan distributif adalah pure moderasi. Hal ini berarti hipotesis kedua $\left(\mathrm{H}_{2}\right)$ diterima, yaitu semakin tinggi partisipasi penganggaran maka semakin rendah senjangan anggaran bagi penyusun anggaran dengan persepsi keadilan distributif tinggi.

Jawaban responden menunjukkan apabila keadilan distributif terlaksana dengan baik dan mencerminkan kebutuhan setiap departemen maka senjangan anggaran yang diakibatkan oleh adanya proses partisipasi penganggaran dapat berkurang. Keadilan distributif yang baik akan menciptakan kepercayaan dalam diri bawahan kepada atasan mereka. Keadilan dan kepercayaan tersebut akan berdampak pada komitmen tujuan anggaran, dimana hal tersebut dapat mengurangi terjadinya senjangan anggaran.

Pada Tabel 3 dapat dilihat bahwa koefisien ketidakpastian lingkungan $\left(\beta_{4}\right)$ sebesar -1,778 dengan nilai signifikansi 0,073 lebih besar dari $\alpha(0,073>0,05)$. Nilai koefisien interaksi $\left(\beta_{7}\right)$ antara ketidakpastian lingkungan dan partisipasi 
ISSN: 2302-8556

E-Jurnal Akuntansi Universitas Udayana Vol.22.2. Februari (2018): 1363-1388

penganggaran sebesar 3,435 dengan nilai signifikansi sebesar 0,024 lebih kecil dari $\alpha$ $(0,024<0,05)$. Nilai koefisien yang tidak signifikan pada variabel bebas dan nilai koefisien yang signifikan pada variabel interaksinya menandakan bahwa status dari ketidakpastian lingkungan adalah pure moderasi. Hal ini berarti hipotesis ketiga $\left(\mathrm{H}_{3}\right)$ diterima, yaitu semakin tinggi partisipasi penganggaran maka semakin tinggi senjangan anggaran bagi penyusun anggaran yang menghadapi kondisi ketidakpastian lingkungan rendah.

Jawaban dari responden terkait item pernyataan pada ketidakpastian lingkungan cenderung memberikan jawaban setuju yang artinya rata-rata responden menghadapi ketidakpastian lingkungan yang rendah (stabil) dalam proses penyusunan anggaran. Hal tersebut dikarenakan manajer tidak menghadapi kesulitan untuk memeroleh informasi yang dibutuhkan sehingga manajer dapat memastikan tindakantindakan apa yang dapat dilakukan untuk menyelesaikan pekerjaan sesuai dengan sasaran anggaran. Ketidakpastian lingkungan yang rendah mendorong terjadinya senjangan anggaran, karena ketika manajer memiliki seluruh informasi untuk memprediksi keadaan lingkungannya maka manajer akan cenderung menyimpan seluruh informasi yang dimilikinya dan memberikan informasi yang bias kepada atasan sehingga terjadi asimetri informasi dan mendorong manajer untuk melakukan slack. Pengaruh kemajuan teknologi informasi juga menjadi alasan yang memudahkan manajemen hotel dalam mengakses data sehingga dapat mengendalikan aktivitas bisnisnya baik internal maupun eksternal hotel. 


\section{SIMPULAN}

Berdasarkan hasil penelitian yang diperoleh melalui pengujian statistik serta pembahasan maka dapat disimpulkan bahwa: Keadilan prosedural merupakan pure moderasi yang mampu memoderasi secara negatif (memperlemah) pengaruh partisipasi penganggaran terhadap senjangan anggaran. Keadilan distributif merupakan pure moderasi yang mampu memoderasi secara negatif (memperlemah) pengaruh partisipasi penganggaran terhadap senjangan anggaran. Ketidakpastian lingkungan merupakan pure moderasi yang mampu memoderasi secara positif (memperkuat) pengaruh partisipasi penganggaran terhadap senjangan anggaran.

Berdasarkan hasil penelitian dan simpulan di atas, maka saran yang dapat diberikan adalah senjangan harus diminimalisir agar dapat meningkatkan efektivitas anggaran pada hotel, karena dengan adanya senjangan anggaran tentu akan merugikan dan dapat menurunkan kinerja perusahaan karena sumber daya perusahaan tidak dimanfaatkan secara maksimal. Peneliti menyarankan kepada pemilik perusahaan (principal) untuk meninjau ulang target anggaran agar tidak terlalu ketat. Hal ini dilakukan agar senjangan anggaran yang terjadi dapat dikurangi dan anggaran yang ditetapkan sesuai dengan kemampuan sesungguhnya dari para manajer (agent). Kepada manajemen dalam menerapkan keadilan prosedural agar tidak memihak antara departemen satu dengan yang lainnya. Dalam hal keadilan distributif sebaiknnya pimpinan dapat meninjau ulang batasan anggaran dalam setiap departemen agar anggaran yang ditetapkan wajar dan adil sehingga senjangan anggaran dapat diminimalisir. Penelitian selanjutnya perlu dilakukan untuk menguji 
ISSN: 2302-8556

E-Jurnal Akuntansi Universitas Udayana Vol.22.2. Februari (2018): 1363-1388

pengaruh moderasi karena berdasarkan nilai adjusted $R$-Square tersisa sebesar 37,7\% yang masih dipengaruhi oleh variabel lain yang tidak dimasukkan dalam model seperti, reward dan punishment serta asimetri informasi. Selain itu sampel yang digunakan dalam penelitian ini hanya terbatas pada hotel berbintang di Kabupaten Badung, maka perlu dilakukan penelitian kembali pada jenis perusahaan yang berbeda pada lokasi yang sama atau perusahaan sejenis pada lokasi yang berbeda.

\section{REFERENSI}

Ajibolade, S.O. and Akinniyi, O.K. 2013. The Influence of Organisational Culture and Budgetary Participation on Propensity to Create Budgetary Slack in Public Sector Organisations. British Journal of Arts and Social Scienes, 13(1), pp: 6983.

Anggariani, P.A. dan Wirama D.G. 2016. Karakteristik Personal sebagai Pemoderasi Pengaruh Penganggaran Partisipatif dan Keterlibatan Kerja Pada Senjangan Anggaran. E-Jurnal Akuntansi Universitas Udayana, 17(1), h: 715-742.

Apriyandi. 2011. Pengaruh Informasi Asimetri terhadap Hubungan antara Anggaran Partisipatif dengan Budgetary Slack. Skripsi Sarjana Ekonomi Jurusan Akuntansi pada Fakultas Ekonomi dan Bisnis Universitas Hasanudin, Makassar.

Ariawan, P., Wirakusuma, G. dan Ratnadi, D. 2015. Keadilan Prosedural dan Iklim Kerja Etis sebagai Pemoderasi Pengaruh Partisipasi Penganggaran pada Senjangan Anggaran (Studi Empiris Pada Pemerintah Kabupaten Tabanan). EJurnal Ekonomi dan Bisnis Universitas Udayana, 7(4), h: 489-500.

Arista, Y.M., Suartana, I.W. dan Budiasih, I.G.A.N. 2016. Keadilan Distributif dan Komitmen Organisasional sebagai Pemoderasi Pengaruh Partisipasi Penganggaran pada Senjangan Anggaran. E-Jurnal Ekonomi dan Bisnis Universitas Udayana, 4(5), h:1031-1056.

Asak, P.R.A., Gerianta Wirawan Yasa, dan Putra Astika I.B. 2016. Kemampuan Asimetri Informasi, Ketidakpastian Lingkungan, Budget Emphasis, dan Kapasitas Individu sebagai Variabel Moderasi Terhadap Partisipasi Anggaran pada Budgetary Slack. E-Jurnal Ekonomi dan Bisnis Universitas Udayana, 2(5), h: 219-228. 
Badan Pusat Statistik Provinsi Bali. 2017. Konsep dan Definisi Statistik Hotel. http://bali.bps.go.id/Subjek/view/is/16. Diakses pada tanggal 12 Agustus 2017.

Colquitt, J. A. and Rodell, J. B. 2015. Measuring Justice and Fairness. The Oxford Handbook of Justice in the Workplace, pp: 187-202.

Desmayani, N.M.M.R. dan Sadha Suardikha, I.M. 2016. Pengaruh Penganggaran Partisipatif, Locus of Control, dan Pemberian Reward Terhadap Budgetary Slack. E-Jurnal Akuntansi Universitas Udayana, 16(2), h: 1121-1148.

Dinas Pariwisata Pemerintah Provinsi Bali. 2017. Kunjungan Wisatawan dan Tingkat Hunian Kamar Hotel Berbintang. Denpasar.

Falikhatun. 2007. Pengaruh Anggaran Partisipatif terhadap Senjangan Anggaran dengan Variabel Pemoderasi Ketidakpastian Lingkungan dan Kohesivitas Kelompok. Jurnal Akuntansi dan Keuangan, 6(2), h: 18-28.

Faria,J.A. and Silva, S.M.G. 2013. The Effects of Information Asymmetry on Budget Slack: An Experimental Research. African Journal of Business Management, 7(13), pp: 1086-1099.

Ghozali, Imam. 2013. Aplikasi Analisis Multivariat dengan Program IBM SPSS 21. Edisi Ketujuh. Semarang: Badan Penerbit Universitas Diponegoro.

Govindarajan, V. 1986. Impact of Participation in The Budgetary Process on Managerial Attitudes and Performance: Universalitic and Contingency Perspective. Decision Sciences, 17, pp: 496-516.

Hansen, Don R., dan Maryanne M. Mowen. 2009. Managerial Accounting. Edisi Delapan. Jakarta: Salemba Empat.

Harryanto. 2017. The Effect Budget Satisfaction, and Organizational Fairness in Local Government Budget Participation Process. Review of Integrative Business and Economics Research, 6(1), pp: 44-74.

Ikhsan, Arfan Lubis. 2010. Akuntansi Keperilakuan.Edisi 2. Jakarta: Salemba Empat.

Jensen, M. and Meckling, W. H. 1976. Theory of the firm: Managerial behavior, agency costs and ownership structure. Journal of Financial Economics, 3(4), pp: $305-360$. 
ISSN: 2302-8556

E-Jurnal Akuntansi Universitas Udayana Vol.22.2. Februari (2018): 1363-1388

Karsam. 2013. The Influence of Participation in Budgeting on Budgetary Slack with Information Asymmetry as a Moderating Variabel and Its Impact on the Managerial Performance (A Study on Yayasan Pendidikan dan Koperasi in the Province of Banten, Indonesia). International Journal of Applied Finance and Business Studies, 1(1), pp: 28-38.

Kartika, Andi. 2010. Pengaruh Komitmen Organisasi dan Ketidakpastian Lingkungan dalam Hubungan Antara Partisipasi Anggaran dengan Senjangan Anggaran (Studi Empirik Pada Rumah Sakit Swasta di Kota Semarang). Journal Kajian Akuntansi, 2(1), h: 39-60.

Kren, L. 2015. Efects of Uncertainty, Participation, and Control System Monitoring on The Prospensity to Create Budget Slack and Actual Budget Slack Created. Advanced in Management Accounting, 11(2), pp. 143-167.

Linn, G, Casey, K Michael Johnson, Gene H Ellis, and T Selwyn. 2016 . Do Broad Scope Managerial Accounting Systems Moderate the Effects of Budget Emphasis, Budget Participation and Perceived Environmental Uncertainty on the Propensity to Create Budgetary. Journal of Computer Information System, 4417, pp. 90-96.

Mahadewi, A.A.S.S. 2014. Pengaruh Partisipasi Penganggaran pada Senjangan Anggaran dengan Asimetri Informasi dan Komitmen Organisasi sebagai Pemoderasi. E-Jurnal Akuntansi Universitas Udayana, 3(8), h: 458-473.

Maiga, A.S. and Jacobs, F.A. 2007. Budget Participation's Influence on Budget Slack: The Role of Persepsi Keadilan, Trust and Goal Commitment. 5(1), pp: 39-58.

Maria, Delli. 2012. Influence Of Distributif Justice and Prosedural Justice Perception On Budgetary Slack: Study Experiment On Participatory Budgeting Context. Malaysia Indonesia Conference on Economics, Management and Accounting, pp: 698-700.

Nitiari, Ni Luh Nyoman. dan Yadnyana, I.K. 2015. Pengaruh Partisipasi Penganggaran, Komitmen Organisasi, dan Ketidakpastian Lingkungan pada Senjangan Anggaran. E-Jurnal Akuntansi Universitas Udayana, 1(11), h: 143154. 
Noviawati, Ika. 2014. Pengaruh Locus of Control, Keadilan Distributif, Keadilan Prosedural, dan Kepercayaan Terhadap Senjangan Anggaran. Skripsi. Sarjana Ekonomi Jurusan Akuntansi Pada Fakultas Ekonomika dan Bisnis Universitas Satya Wacana Salatiga.

Osama, Mah'd. H.A, Mohammed Idris, and Abdulhadi Ramadan. 2013. The Impact of Budgetary Participation on Managerial Performance: Evidence from Jordanian University Executives. Journal of Applied Finance \& Banking, 3(3), pp: $133-156$.

Otley, D.T. 1978. Budget Use and Managerial Performance. Journal of Accounting Research, 16(1), pp: 122-149.

Ozer, G. and Yilmaz, E. 2011. Effects of Prosedural Justice Perception , Budgetary Control Effectiveness and Ethical Work Climate on Propensity to Create Budgetary Slack. Business and Economics Research Journal, 2(4), pp: 1-18.

Perdana, K.W. dan Gerianta Wirawan Yasa. 2017. Pengaruh Partisipasi Penyusunan Anggaran Pada Budgetary Slack dengan Komitmen Organisasi dan Etika Sebagai Variabel Moderasi. E-Jurnal Akuntansi Universitas Udayana, 18(3), h: 2346-2372.

Perhimpunan Hotel \& Restoran Indonesia. 2017. Anggota PHRI Bali di Badung. www.phribali.or.id/tentang-phri/daftar-anggota/badung. Diakses pada tanggal 12 Agustus 2017.

Pratami, Desi A. A. SG. dan Adi Erawati Ni Made. 2016. Pengaruh Partisipasi Penganggaran Terhadap Senjangan Anggaran Dengan Penekanan Anggaran dan Ketidakpastian Lingkungan Sebagai Pemoderasi. E-Jurnal Akuntansi Universitas Udayana, 15(2), pp: 1565-1594.

Raghunandan, M., Ramgulam, N. and Mohammed, K.R. 2012. Examining the Behavioural Aspects of Budgeting with particular emphasis on Public Sector/Service Budgets. International Journal of Business and Social Science, 3(14), pp: 107-116.

Ramdeen, C., Santos, J. and Chatfield, H.Y. 2007. An Examination of Impact of Budgetary Participation, Budget Emphasis, and Information Asymmetry on Budgetary Slack in the Hotel Industry. (702), pp: 1-15. 
ISSN: 2302-8556

E-Jurnal Akuntansi Universitas Udayana Vol.22.2. Februari (2018): 1363-1388

Resen, N.S.K. 2014. Pengaruh Partisipasi Anggaran, Self Esteem dan Budget Emphasis Terhadap Budgetary Slack Pada Hotel Berbintang di Denpasar. EJurnal Akuntansi Universitas Udayana, 1(10), h: 1-13.

Rhaudhiah, Noor, Rozita Amiruddin, and Sofiah Md Auzair. 2014. Impact of Organisational Factors On Budgetary Slack. Journal of Management and Muamalah, pp: 20-34.

Saputra, K.D., dan Wijana Asmara Putra, I.N. 2017. Pengaruh Partisipasi Anggaran dan Asimetri Informasi pada Senjangan Anggaran dengan Komitmen Organisasi Sebagai Variabel Pemoderasi. E-Jurnal Akuntansi Universitas Udayana, 19(1), h: 223-250.

Stede, Wim A. 2000. The Relationship Between Two Consequences of Budgetary Controls: Budgetary Slack Creation and Managerial Short-term Orientation. Journal of Accounting Organizations and Society, 25, pp: 609-622.

Suartana, I.W. 2010. Akuntansi Keprilakuan Teori dan Implementasi. Yogyakarta: ANDI.

Sugiyono, 2013. Metode Penelitian Bisnis. Edisi Ketujuh Belas. Bandung: CV. Alfabeta.

Sujana, I Ketut. 2010. Pengaruh Partisipasi Penganggaran, Penekanan Anggaran, Komitmen Organisasi, Asimetri Informasi, dan Ketidakpastian Lingkungan Terhadap Budgetary Slack pada Hotel-Hotel Berbintang di Kota Denapasar. Jurnal Ilmiah Akuntansi dan Bisnis Universitas Udayana, 5(2), h: 101-126.

Suprasto, Bambang. 2006. Pengaruh Interaksi Antara Partisipasi Anggaran, Informasi Asimetris, dan Penekanan Anggaran terhadap Budgetary Slack (Studi Kasus di Hotel - Hotel di Provinsi Bali). Audit Jurnal Akuntansi dan Bisnis. Vol. 1, h: 75-86.

Tagwireyi, Frank. 2012. An Evaluation of Budgetary Slack in Public Institutions in Zimbabwe. International Journal of Economic Research, 3(4), pp:38-41.

Widanaputra, A. A. G. P., Herkulanus Bambang S., Dodik Ariyanto, dan Ratna Sari. 2009. Akuntansi Perhotelan (Pendekatan Sistem Informasi). Yogyakarta: Graha Ilmu. 
Widanaputra, A.A.G.P and Mimba, N.P.S.H. 2014. The Influence of Participative Budgeting on Budgetary Slack in Composing Local Governments Budget in Bali Province. Procedia - Social and Behavioral Sciences. Elsevier B.V., 164, pp: 391-396.

Wijayanthi, P.K. dan Widanaputra, A.A.G.P. 2016. Pengaruh Partisipasi Penganggaran pada Senjangan Anggaran Dengan Kepercayaan Diri dan Ketidakpastian Lingkungan sebagai Pemoderasi. E-Jurnal Akuntansi Universitas Udayana, 15(1), h: 695-726.

Yilmaz, E. and Özer, G. 2011. The Effects of Environmental Uncertainty and Budgetary Control Effectiveness on Propensity to Create Budgetary Slack in Public Sector. African Journal of Business Management, 5(22), pp: 89028908 .

Young, S. Mark. 1985. Participative Budgeting: The Effects of Risk Aversion and Asymmetric Information on Budgetary Slack. Journal of Accounting Research, 23(2), pp: 829-842.

Zainuddin, Suria. 2013. Distributif Fairness and Motivating In Participative Budgeting Setting. 1(139), pp: 292-301. 